\title{
Determination of Energy and Protein Requirements of Sheep in Indonesia using a Meta-analytical Approach
}

\author{
A. Jayanegara*, M. Ridla, D. A. Astuti, K. G. Wiryawan, E. B. Laconi, \& Nahrowi \\ Department of Animal Nutrition and Feed Technology, Faculty of Animal Science, Bogor Agricultural University \\ Kampus IPB Darmaga, Bogor 16680, Indonesia \\ (Received 26-04-2017; Reviewed 04-07-2017; Accepted 18-07-2017)
}

\begin{abstract}
The objective of this study was to determine energy and protein requirements, for both maintenance and gain, of sheep in Indonesia by using a meta-analysis method. A database was developed from various in vivo experiments involving sheep as the experimental animals in which energy intake, protein intake and average daily weight gain (ADG) were reported. A total of 38 articles consisting of 137 data points were integrated into the database. Different breeds (Priangan, fat-tailed and local) and sexes (male and female) were specified in the database. Maintenance and gain requirements of dry matter, energy and protein were determined by regressing ADG with dry matter intake (DMI), total digestible nutrient intake (TDNI) and crude protein intake (CPI), respectively. An intercept (where $\mathrm{ADG}=0 \mathrm{~g} / \mathrm{kg} \mathrm{MBW/d}$ ) and a slope (required nutrient intake per unit ADG) were taken as maintenance and gain requirements, respectively. Results revealed that all sheep breeds had similar energy requirement for maintenance $\left(\mathrm{TDN}_{\mathrm{m}}\right)$. Energy requirement for gain $\left(\mathrm{TDN}_{\mathrm{o}}\right)$ of Priangan breed was lower than other breeds; the breed required $0.860 \mathrm{~g}$ TDN for $1 \mathrm{~g}$ ADG. Fat-tailed and local breeds required 1.22 and $2.75 \mathrm{~g}$ TDN for $1 \mathrm{~g}$ ADG, respectively. All breeds also revealed relatively similar protein requirement for maintenance $\left(\mathrm{CP}_{\mathrm{m}}\right)$, i.e. $6.27-6.47 \mathrm{~g} / \mathrm{kg} \mathrm{MBW} / \mathrm{d}$. Priangan breed required less CP for $1 \mathrm{~g}$ ADG $\left(\mathrm{CP}_{\mathrm{g}}\right)$, i.e. $0.295 \mathrm{~g}$. Requirements of $\mathrm{CP}_{\mathrm{g}}$ for fat-tailed and local breeds were 0.336 and $0.497 \mathrm{~g} / \mathrm{g}$ ADG, respectively. It was concluded that each sheep breed in Indonesia had specific TDN and CP requirements for gain, but similar requirements for maintenance.
\end{abstract}

Keywords: nutrient requirement, energy, protein, sheep, meta-analysis

\section{ABSTRAK}

Penelitian ini bertujuan untuk menentukan kebutuhan energi dan protein domba di Indonesia menggunakan metode meta-analisis. Berbagai eksperimen pakan/nutrisi yang menggunakan domba dan melaporkan peubah konsumsi energi, konsumsi protein dan pertambahan bobot badan (PBB) ditabulasi dalam suatu database. Sebanyak 38 artikel yang terdiri atas 137 data diintegrasikan pada database tersebut. Bangsa domba yang berbeda (Priangan, ekor gemuk dan lokal) dan jenis kelamin (jantan dan betina) juga diinformasikan. Kebutuhan hidup pokok dan pertumbuhan untuk bahan kering (BK), energi (TDN) dan protein (PK) didapatkan melalui regresi antara PBB dengan konsumsi BK, konsumsi TDN dan konsumsi PK. Kebutuhan hidup pokok didapatkan melalui nilai intersep regresi (ketika $\mathrm{PBB}=0 \mathrm{~g} / \mathrm{kg}$ bobot badan metabolik $[\mathrm{BBM}] /$ hari) sedangkan kebutuhan pertumbuhan adalah nilai kemiringan (konsumsi per unit PBB) dari persamaan regresi. Hasil menunjukkan bahwa semua bangsa domba yang diamati memiliki kebutuhan energi untuk hidup pokok $\left(\mathrm{TDN}_{\mathrm{m}}\right.$ ) yang sama. Kebutuhan energi untuk pertumbuhan $\left(\mathrm{TDN}_{\mathrm{g}}\right)$ dari domba priangan lebih rendah dibandingkan dengan bangsa domba lainnya; domba priangan membutuhkan 0,860 g TDN untuk setiap $1 \mathrm{~g}$ PBB. Domba ekor gemuk dan domba lokal membutuhkan 1,22 dan 2,75 g TDN untuk setiap $1 \mathrm{~g}$ PBB. Semua bangsa domba tersebut memiliki kebutuhan protein untuk hidup pokok yang sama $\left(\mathrm{CP}_{\mathrm{m}}\right)$, yakni sekitar 6,27-6,47 g/kg BBM/hari. Kebutuhan protein untuk pertumbuhan $\left(\mathrm{CP}_{\mathrm{g}}\right)$ dari domba priangan, domba ekor gemuk dan domba lokal adalah 0,295, 0,336 dan 0,497 g/g PBB. Disimpulkan bahwa setiap bangsa domba di Indonesia memiliki kebutuhan energi dan protein untuk pertumbuhan yang spesifik, namun memiliki kebutuhan hidup pokok yang sama.

Kata kunci: kebutuhan nutrisi, energi, protein, domba, meta-analisis

${ }^{*}$ Corresponding author:

E-mail: anuraga.jayanegara@gmail.com 


\section{INTRODUCTION}

Current practice of ration formulation for various livestock in Indonesia, either ruminants (beef cattle, dairy cattle, sheep and goat) or monogastrics (poultry and swine), follows feeding standards developed in other countries, particularly National Research Council (NRC) standard of the USA (Indarsih, 2009; Baihaqi \& Herman, 2012; Lestari et al., 2015). Although other feeding standards such as from UK (AFRC), France (INRA), Australia (CSIRO) and Dutch (VEM-DVE) are available, they are rarely used in the country. However, using standard from other country may not be suitable because of a number of considerable differences such as (1) feed ingredient and nutritional quality, (2) environmental condition, and (3) animal breed and genetics (Salah et al., 2014). It is well accepted that different feed and environmental condition (tropics vs temperate), for instance, affect nutrient utilization and partition, animal growth, body composition and, hence, energy and protein requirements of animals. Further, regarding animal breed and genetics, Bos indicus breeds have $10 \%$ less net energy for maintenance requirement than Bos taurus breeds (NRC, 2000; Chizzotti et al., 2008). Thus, it is apparent that developing our own feeding standard is essential for animals under local condition in Indonesia.

A feeding standard generally has two parts, i.e. (1) nutrient requirement of animals, specific per species and at different physiological stages and (2) chemical composition of feedstuffs. The feeding standard has to, in turn, contribute to optimal diet formulation and allows proper nutritional management in an efficient, technical and economical way. Methods for determining energy and protein requirements of animals are mostly based on (1) calorimetric method and (2) comparative slaughter method. The calorimetric method uses respiration chamber to measure gas exchange, heat production during fasting, and loss of energy through urine and methane at maintenance level of animal feeding (Dong et al., 2015). The comparative slaughter method employs feeding trials in which animals are fed at two or more levels of intake, and one of them is at maintenance level. Metabolizable energy (ME) intake and retained energy (RE) as the change in body energy content of animals are measured through this procedure. The slope of linear regression between RE and ME intake indicates efficiency of ME utilization or ME for gain (Chizzotti et al., 2007; Zhao et al., 2016). Both methods require relatively sophisticated research facilities and financial resources to perform the experiments in which these are among the main obstacles in Indonesia. Further, it may take quite long time to generate data from different experiments so that the energy and protein requirements are accurate and reliable.

A more recent method of determining nutrient requirements of animals is meta-analysis study using data from feeding trials across various independent experiments (Chizzotti et al., 2008; Salah et al., 2014; Oliveira, 2015). Although meta-analysis studies have been conducted by Indonesian researchers (Palupi et al., 2012; Jayanegara et al., 2014), the method has not been applied to the determination of nutrient requirement of animals in Indonesia. This method seems suitable for us since significant amount of data have already been generated on feed or nutrient intake, nutrient digestibility and production performance of animals. To date, determination of nutrient requirement on sheep by using a meta-analytical approach worldwide is scarce (Salah et al., 2014). The objective of this study was, therefore, to determine energy and protein requirements, for both maintenance and gain, of sheep in Indonesia by using a meta-analytical approach. Since this is the first study of such objective in Indonesia, determination of nutrient requirement of other livestock species are subjected to further sequential studies provided that the results obtained are proved to be accurate and reliable through further studies.

\section{MATERIALS AND METHODS}

\section{Database Development}

A database was constructed from published articles on feeding trials involving sheep as the experimental animals and in which the experiments were performed in Indonesia. The articles were obtained from various Indonesian journals related to animal science, i.e. (1) Media Peternakan, (2) Jurnal Pengembangan Peternakan Tropis, (3) Buletin Peternakan, (4) Jurnal Ilmu Ternak dan Veteriner, (5) Jurnal Peternakan Integratif, (6) Jurnal Agripet, (7) Jurnal Ilmu-ilmu Peternakan, and (8) Jurnal Ilmu Ternak. In each journal website, literature search was conducted with a keyword "sheep". All full text articles found were evaluated for their suitability to be included in the database. Minimum criteria for an article to be included in the database were that intial body weight $\left(\mathrm{BW}_{0}\right)$, average daily gain (ADG), dry matter intake (DMI) of sheep, and chemical composition of the ration used (at least crude protein content) were reported.

A total of 38 articles consisting of 137 data points (represented different dietary treatments) were integrated into the database (Mathius et al., 1996; 1997; 1998; Thalib et al., 1996; 2010; Lubis et al., 1998; 2002; Mahyuddin, 2001; Duldjaman, 2004; Tarmidi, 2004; Adawiyah et al., 2006; Puastuti et al., 2006; Uhi, 2006; Supriati \& Haryanto, 2007; Wiryawan et al., 2007; Sudarman et al., 2008; Supriyati, 2008; Tanuwiria \& Ayuningsih, 2008; Thalib \& Widiawati, 2008; Zain, 2009; Hartutik et al., 2010; Hernaman et al., 2011; Widiyanto et al., 2011; 2012; Rimbawanto et al., 2012; Ginting et al., 2013; Ketaren et al., 2013; Sitanggang et al., 2013; Braymana et al., 2014; Ekawati et al., 2014; Khotijah et al., 2014; Nababan et al., 2014; Ndaru et al., 2014; Wulandari et al., 2014; Aqbari et al., 2015; Simanjuntak et al., 2015; Tiven et al., 2015; Wati et al., 2015). Different breeds (Priangan, fat-tailed and local) and sexes (male and female) were specified in the database. Initially there was also Sumatra sheep but the data were excluded due to scarcity of articles available (Puastuti et al., 2010; Yulistiani et al., 2011; 2013). Parameters included were dry matter intake (DMI), crude protein intake (CPI), 
ether extract intake (EEI), crude fiber intake (CFI), neutral detergent fiber intake (NDFI), acid detergent fiber intake (ADFI), total digestible nutrient intake (TDNI), average daily gain (ADG), gain to feed ratio (G:F), dry matter digestibility (DMD), rumen ammonia $\left(\mathrm{NH}_{3}\right)$ concentration and total volatile fatty acid (VFA) concentration. Parameters related to intake and ADG were expressed in relation to metabolic body weight (MBW, i.e $\mathrm{BW}^{0.75}$ ) to account for variation due to different body weight of sheep. Data within a parameter were transformed into a similar measurement unit in order to allow direct analysis. Summary of the database used in the meta-analysis is presented in Table 1.

\section{Data Analysis}

Meta-analysis was performed by using a mixed model statistics (St-Pierre, 2001; Sauvant et al., 2008) in which different studies were considered as random effects whereas different breeds, sexes and nutrient intake were considered as fixed effects. Interaction between breed $\times$ sex, breed $\times$ intake, sex $\times$ intake and breed $\times$ sex $\times$ intake on dependent variables were initially tested. Any insignificant interactions were then removed from the statistical model. Significance of an effect was stated at $P<0.05$. Qualitative information such as study, breed and sex were stated in the class statement.

Table 1. Descriptive statistics of database used in meta-analysis

\begin{tabular}{|c|c|c|c|c|c|c|c|}
\hline Parameter & Unit & Breed & $\mathrm{N}$ & Mean & SD & Min & Max \\
\hline \multirow[t]{3}{*}{ DMI } & $\mathrm{g} / \mathrm{kg}$ & Local & 88 & 81.7 & 20.0 & 42.6 & 135 \\
\hline & MBW/d & Priangan & 33 & 79.9 & 19.5 & 43.1 & 109 \\
\hline & & Fat-tailed & 16 & 69.9 & 9.89 & 59.6 & 93.8 \\
\hline \multirow[t]{3}{*}{ CPI } & $\mathrm{g} / \mathrm{kg}$ & Local & 88 & 10.8 & 3.20 & 4.65 & 21.1 \\
\hline & MBW/d & Priangan & 33 & 11.4 & 2.76 & 5.90 & 17.5 \\
\hline & & Fat-tailed & 16 & 9.76 & 1.17 & 7.58 & 11.7 \\
\hline \multirow[t]{3}{*}{ EEI } & $\mathrm{g} / \mathrm{kg}$ & Local & 46 & 4.63 & 2.92 & 0.690 & 12.6 \\
\hline & MBW/d & Priangan & 30 & 3.54 & 2.36 & 1.43 & 12.2 \\
\hline & & Fat-tailed & 4 & 5.27 & 0.459 & 4.67 & 5.67 \\
\hline \multirow[t]{3}{*}{ CFI } & $\mathrm{g} / \mathrm{kg}$ & Local & 46 & 18.2 & 7.59 & 7.46 & 39.4 \\
\hline & MBW/d & Priangan & 30 & 14.0 & 7.41 & 5.41 & 27.8 \\
\hline & & Fat-tailed & 9 & 11.6 & 2.40 & 8.46 & 14.5 \\
\hline \multirow[t]{3}{*}{ NDFI } & $\mathrm{g} / \mathrm{kg}$ & Local & 34 & 40.6 & 7.84 & 28.5 & 54.4 \\
\hline & MBW/d & Priangan & 5 & 43.7 & 3.32 & 40.3 & 48.0 \\
\hline & & Fat-tailed & na & na & na & na & na \\
\hline \multirow[t]{3}{*}{ ADFI } & $\mathrm{g} / \mathrm{kg}$ & Local & 28 & 23.1 & 5.63 & 14.3 & 31.7 \\
\hline & MBW/d & Priangan & 5 & 27.0 & 3.87 & 22.6 & 32.0 \\
\hline & & Fat-tailed & na & na & na & na & na \\
\hline \multirow[t]{3}{*}{ TDNI } & $\mathrm{g} / \mathrm{kg}$ & Local & 46 & 53.3 & 17.9 & 17.1 & 95.8 \\
\hline & MBW/d & Priangan & 26 & 49.7 & 12.5 & 27.6 & 67.2 \\
\hline & & Fat-tailed & 9 & 43.9 & 3.47 & 39.6 & 49.1 \\
\hline \multirow[t]{3}{*}{ ADG } & $\mathrm{g} / \mathrm{kg}$ & Local & 88 & 10.1 & 3.52 & 2.26 & 21.1 \\
\hline & MBW/d & Priangan & 33 & 10.4 & 5.71 & 1.90 & 26.9 \\
\hline & & Fat-tailed & 16 & 10.0 & 5.09 & 3.14 & 16.7 \\
\hline \multirow[t]{3}{*}{ G:F } & $\%$ & Local & 88 & 13.0 & 5.64 & 2.39 & 38.4 \\
\hline & & Priangan & 33 & 12.4 & 4.52 & 4.41 & 24.9 \\
\hline & & Fat-tailed & 16 & 15.0 & 8.46 & 4.61 & 24.4 \\
\hline \multirow[t]{3}{*}{ DMD } & $\%$ & Local & 45 & 57.5 & 6.46 & 49.0 & 73.6 \\
\hline & & Priangan & 12 & 61.2 & 10.7 & 43.8 & 76.0 \\
\hline & & Fat-tailed & 16 & 74.1 & 5.52 & 64.5 & 83.1 \\
\hline \multirow[t]{3}{*}{$\mathrm{NH}_{3}$} & $\mathrm{mmol} / \mathrm{L}$ & Local & 6 & 9.06 & 1.57 & 7.10 & 10.9 \\
\hline & & Priangan & 12 & 6.55 & 2.70 & 3.06 & 11.0 \\
\hline & & Fat-tailed & 4 & 5.16 & 1.18 & 3.70 & 6.35 \\
\hline \multirow[t]{3}{*}{ Total VFA } & $\mathrm{mmol} / \mathrm{L}$ & Local & 6 & 114 & 35.6 & 73.5 & 150 \\
\hline & & Priangan & 8 & 111 & 7.69 & 95.0 & 118 \\
\hline & & Fat-tailed & 4 & 175 & 15.3 & 162 & 194 \\
\hline
\end{tabular}

Note: N, number of data; SD, standard deviation; DMI, dry matter intake; CPI, crude protein intake; EEI, ether extract intake; CFI, crude fiber intake; NDFI, neutral detergent fiber intake; ADFI, acid detergent fiber intake; TDNI, total digestible nutrient intake; ADG, average daily gain; G:F, gain to feed; $\mathrm{DMD}$, dry matter digestibility; $\mathrm{NH}_{3^{\prime}}$ ammonia; VFA, volatile fatty acid; MBW, metabolic body weight (BW0.75); na, data not available. 
Weighting procedure was not applied in the present meta-analysis. An adjustment of dependent variable was performed to create a two-dimensional graphical presentation from multi-dimensional studies by adding the predicted dependent values with their corresponding residuals (St-Pierre, 2001). Maintenance and gain requirements for dry matter, energy and protein were determined by regressing ADG with DMI, TDNI and $\mathrm{CPI}$, respectively. An intercept (where $\mathrm{ADG}=0 \mathrm{~g} / \mathrm{kg}$ $\mathrm{MBW} / \mathrm{d}$ ) and a slope (required nutrient intake per unit ADG) indicated maintenance and gain requirements, respectively. The P-value and coefficient of determination $\left(\mathrm{R}^{2}\right)$ were employed to assess the goodness-of-fit of the statistical model. All statistical analyses were conducted by using SAS Software version 9.1.

\section{RESULTS}

There was a positive relationship between sheep $\mathrm{BW}_{0}$ and DMI (Figure 1); higher $\mathrm{BW}_{0}$ led to a higher DMI $(\mathrm{P}<0.001)$. Interactions between breed, sex and $\mathrm{BW}_{0}$ on DMI were not significant. When DMI was presented as percentage to $\mathrm{BW}_{0}$, the relationship became negative

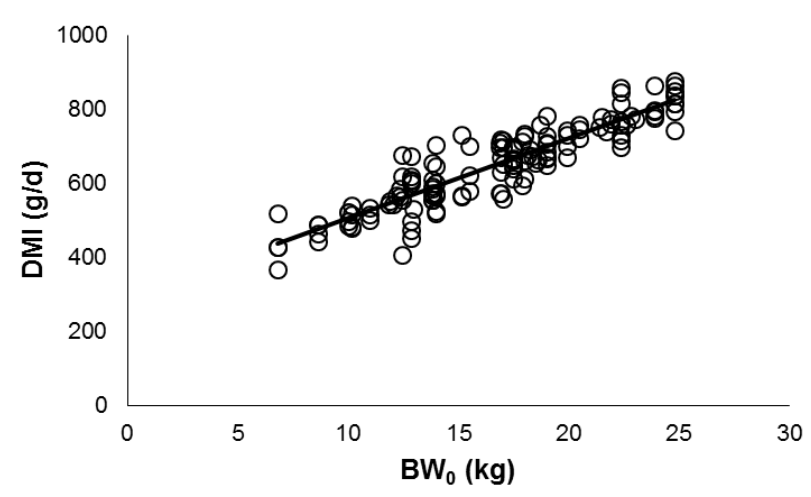

Figure 1. Relationship between initial body weight $\left(\mathrm{BW}_{0^{\prime}} \mathrm{kg}\right)$ and dry matter intake $(\mathrm{DMI}, \mathrm{g} / \mathrm{d})$. DMI $(\mathrm{g} / \mathrm{d})=288+$ $21.6 \mathrm{BW}_{0}(\mathrm{~kg})\left(\mathrm{N}=137 ; \mathrm{P}<0.001 ; \mathrm{R}^{2}=0.829\right)$. All interactions between breed, sex, and $\mathrm{BW}_{0}$ on DMI were insignificant.

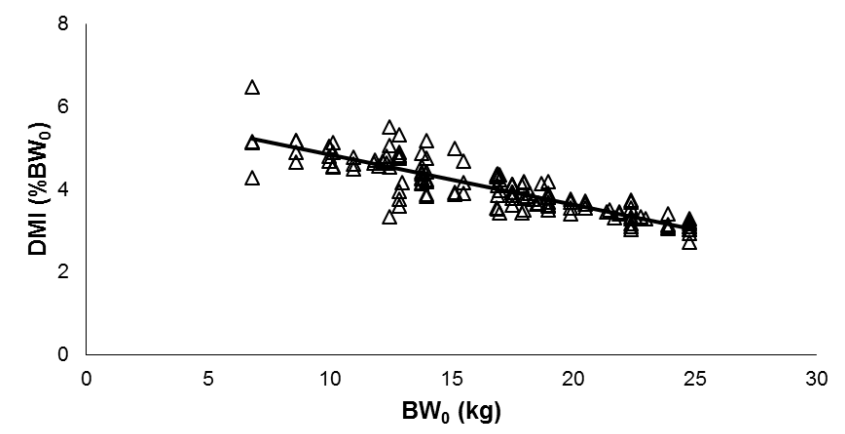

Figure 2. Relationship between initial body weight $\left(\mathrm{BW}_{0^{\prime}} \mathrm{kg}\right)$ and percentage of dry matter intake (DMI) to $\mathrm{BW}_{0}$. DMI $\left(\% \mathrm{BW}_{0}\right)=6.04-0.120 \mathrm{BW}_{0}(\mathrm{~kg})(\mathrm{N}=137 ; \mathrm{P}=0.003$; $\left.R^{2}=0.746\right)$. All interactions between breed, sex, and $\mathrm{BW}_{\circ}$ on DMI were insignificant.
( $\mathrm{P}<0.01$; Figure 2). A positive linear relationship between ADG and DMI was observed $(\mathrm{P}<0.001$; Figure 3$)$; such relationship was similar among different breeds and sex (no significant interaction). Crude protein intake (CPI) positively influenced ADG $(\mathrm{P}<0.001)$ and there was an interaction between CPI and breed on ADG $(\mathrm{P}<0.05$; Table 2). No significant relationships were found between ether extract intake (EEI), crude fiber intake (CFI) and neutral detergent fiber intake (NDFI) on ADG. Similar to CPI, total digestible nutrient intake (TDNI) positively influenced ADG and it was specific for each breed $(\mathrm{P}<0.001)$. The $\mathrm{CPI}$ also positively influenced gain to feed ratio $(\mathrm{G}: \mathrm{F} ; \mathrm{P}<0.01)$. Interactions between EEI and sex on G:F $(\mathrm{P}<0.05)$ and $C F I$ and breed on $\mathrm{G}: \mathrm{F}(\mathrm{P}<0.05)$ were significants. Both NDFI and ADFI negatively influenced $\mathrm{G}: \mathrm{F}(\mathrm{P}<0.05)$ and the interaction between breed, sex and ADFI on G:F was significant $(\mathrm{P}<0.01)$. Intake of nutrients was hardly influenced DMD, rumen ammonia and total VFA concentrations.

All sheep breeds (local, Priangan and fat-tailed) had similar energy requirement for maintenance $\left(\mathrm{TDN}_{\mathrm{m}}\right)$ as shown by the relatively similar intercept values among the breeds (Figure 4). Energy requirement for gain $\left(\mathrm{TDN}_{\mathrm{g}}\right)$ of Priangan breed was lower than other breeds; the breed required $0.860 \mathrm{~g}$ TDN for $1 \mathrm{~g}$ ADG. Fat-tailed and local breeds required 1.22 and $2.75 \mathrm{~g}$ TDN for $1 \mathrm{~g}$ ADG, respectively. All breeds also revealed relatively similar protein requirement for maintenance $\left(\mathrm{CP}_{\mathrm{m}}\right)$, i.e. 6.27-6.47 $\mathrm{g} / \mathrm{kg} \mathrm{MBW/d}$ (Figure 5). Priangan breed required less CP for $1 \mathrm{~g}$ ADG $\left(\mathrm{CP}_{\mathrm{g}}\right)$, i.e. $0.295 \mathrm{~g}$. Requirements of $\mathrm{CP}_{\mathrm{g}}$ for fat-tailed and local breeds were 0.336 and $0.497 \mathrm{~g} / \mathrm{g}$ ADG, respectively. Based on the equations provided in Figure 4 and Figure 5, recommended dry matter, energy and crude protein intake for local, Priangan and fat-tailed sheep in Indonesia is presented in Table 3.

\section{DISCUSSION}

\section{Dry Matter Intake of Sheep}

Feed intake is considered as a primary factor determining performance of livestock. A positive relationship

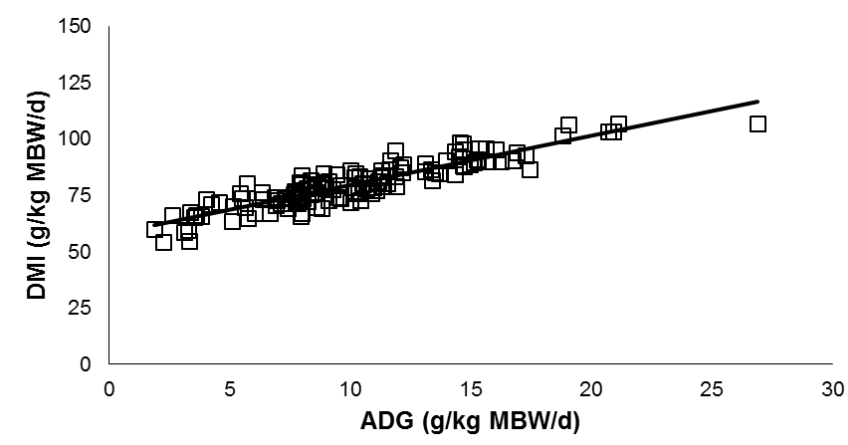

Figure 3. Relationship between dry matter intake (DMI, g/kg $\mathrm{MBW} / \mathrm{d}$ ) and average daily gain (ADG, g/kg MBW/d). DMI $(\mathrm{g} / \mathrm{kg} \mathrm{MBW} / \mathrm{d})=57.6+2.20$ ADG $(\mathrm{g} / \mathrm{kg} \mathrm{MBW} / \mathrm{d})$ $\left(\mathrm{N}=137 ; \mathrm{P}<0.001 ; \mathrm{R}^{2}=0.823\right)$. All interactions between breed, sex, and ADG on DMI were insignificant. 
Table 2. Significancy (P-value) of relationship between independent and dependent variables

\begin{tabular}{|c|c|c|c|c|c|c|c|c|}
\hline Dep & Indep & Breed & Sex & $\mathrm{B} \times \mathrm{S}$ & Indep & $\mathrm{B} \times \mathrm{I}$ & $S \times I$ & $B \times S \times I$ \\
\hline \multirow[t]{7}{*}{ ADG } & DMI & $\mathrm{ns}$ & ns & $\mathrm{ns}$ & 0.005 & ns & ns & ns \\
\hline & CPI & ns & ns & ns & $<0.001$ & 0.037 & $\mathrm{~ns}$ & ns \\
\hline & EEI & ns & ns & na & ns & ns & ns & na \\
\hline & CFI & ns & ns & na & ns & ns & ns & na \\
\hline & NDFI & ns & ns & ns & $\mathrm{ns}$ & ns & ns & ns \\
\hline & ADFI & ns & ns & 0.027 & ns & ns & ns & ns \\
\hline & TDNI & ns & na & na & $<0.001$ & $<0.001$ & na & na \\
\hline \multirow[t]{7}{*}{$\mathrm{G}: \mathrm{F}$} & DMI & ns & ns & $\mathrm{ns}$ & ns & ns & $\mathrm{ns}$ & ns \\
\hline & CPI & ns & ns & ns & 0.009 & ns & ns & ns \\
\hline & EEI & ns & ns & na & ns & ns & 0.044 & na \\
\hline & CFI & ns & $\mathrm{ns}$ & na & $\mathrm{ns}$ & 0.036 & $\mathrm{~ns}$ & na \\
\hline & NDFI & ns & ns & ns & 0.013 & ns & ns & ns \\
\hline & ADFI & ns & ns & $<0.001$ & 0.002 & ns & ns & 0.002 \\
\hline & TDNI & ns & na & na & ns & ns & na & na \\
\hline \multirow[t]{7}{*}{ DMD } & DMI & ns & ns & ns & ns & ns & ns & ns \\
\hline & CPI & ns & ns & ns & ns & ns & ns & ns \\
\hline & EEI & ns & na & na & ns & ns & na & na \\
\hline & CFI & ns & na & na & ns & ns & na & na \\
\hline & NDFI & ns & ns & ns & ns & ns & ns & ns \\
\hline & ADFI & ns & ns & na & ns & ns & ns & na \\
\hline & TDNI & ns & na & na & ns & 0.023 & na & na \\
\hline \multirow[t]{7}{*}{$\mathrm{NH}_{3}$} & DMI & ns & na & na & ns & ns & na & na \\
\hline & CPI & ns & na & na & ns & ns & na & na \\
\hline & EEI & ns & na & na & ns & ns & na & na \\
\hline & CFI & ns & na & na & ns & ns & na & na \\
\hline & NDFI & ns & na & na & ns & ns & na & na \\
\hline & ADFI & na & na & na & ns & na & na & na \\
\hline & TDNI & ns & na & na & ns & ns & na & na \\
\hline Total & DMI & ns & na & na & ns & ns & na & na \\
\hline \multirow[t]{6}{*}{ VFA } & CPI & ns & na & na & ns & ns & na & na \\
\hline & EEI & ns & na & na & ns & ns & na & na \\
\hline & CFI & ns & na & na & ns & ns & na & na \\
\hline & NDFI & $\mathrm{ns}$ & na & na & $\mathrm{ns}$ & $\mathrm{ns}$ & na & na \\
\hline & ADFI & na & na & na & ns & na & na & na \\
\hline & TDNI & ns & na & na & ns & ns & na & na \\
\hline
\end{tabular}

Note: Dep, dependent variable; Indep (I), independent variable; B, breed; S, sex. DMI, dry matter intake; CPI, crude protein intake; EEI, ether extract intake; CFI, crude fiber intake; NDFI, neutral detergent fiber intake; ADFI, acid detergent fiber intake; TDNI, total digestible nutrient intake; ADG, average daily gain; G:F, gain to feed; $\mathrm{DMD}$, dry matter digestibility; $\mathrm{NH}_{3}$, ammonia; VFA, volatile fatty acid; ns, not significant at $\mathrm{P}<0.05$; na, data not available.

between sheep $\mathrm{BW}_{0}$ and DMI was also observed in a meta-analysis study of Riaz et al. (2014). It was observed not only in sheep but also in other domestic ruminant species such as goat, cattle and buffalo. However, when DMI was presented proportionally to $\mathrm{BW}_{0}$ then the relationship turned to be negative. It has been known that intake is directly related to maintenance requirement. With increasing body weight, maintenance requirement per unit of BW decrease and thus feed intake relative to BW decrease as well (Riaz et al., 2014). Using an equation presented in Figure 2, for instance, a sheep with $20 \mathrm{~kg} \mathrm{BW}$ may require a DMI of $3.64 \%$ BW. The value is within the range of sheep DMI with similar BW, i.e. 2.86-3.91\% BW as recommended by NRC (2007). Such
NRC (2007) DMI recommendation range depends on ADG of sheep and energy concentration in the diet. The result was also in close agreement with Kearl (1982) who recommended that DMI of sheep (20 kg BW) ranged from $2.8 \%-3.6 \%$ BW.

Feed intake of ruminants is affected by a number of factors, i.e. dietary, animal and environmental factors (Nikkhah, 2014). Dietary factors affecting feed intake are comprised of feed physical and chemical properties, processing and fermentation rhythms. Animal factors affecting intake include parity, lactation stage (in the case of dairy animals), hormones, body fat stores and distribution, cellular hypoxia and energy flow, and production characteristics, whereas environmental 


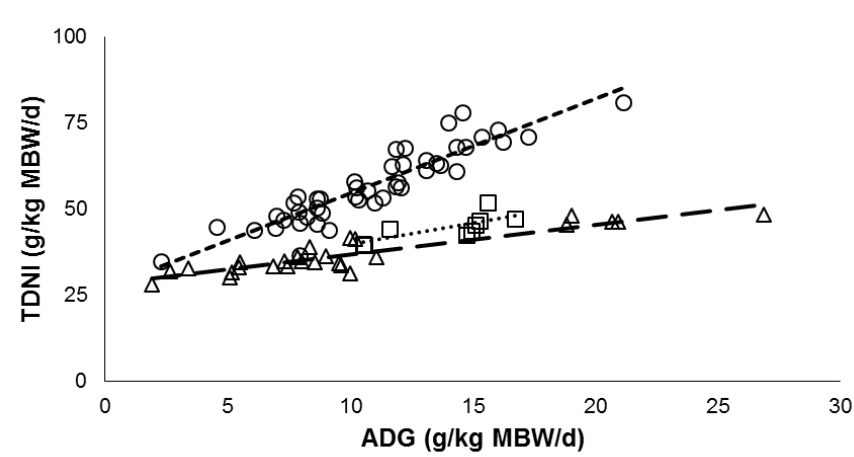

Figure 4. Relationship between total digestible nutrient intake (TDNI, g/kg MBW/d) and average daily gain (ADG, g/ $\mathrm{kg} \mathrm{MBW/d)}$ of local (-o-), Priangan (- $\Delta-)$ and fat-tailed (-口-) sheep breeds.

Local breed : TDNI $(\mathrm{g} / \mathrm{kg} \mathrm{MBW} / \mathrm{d})=27.0+2.75$ ADG $(\mathrm{g} / \mathrm{kg}$ $\mathrm{MBW} / \mathrm{d})$ $\left(\mathrm{N}=46 ; \mathrm{P}<0.001 ; \mathrm{R}^{2}=0.833\right)$

Priangan breed: $\quad$ TDNI $(\mathrm{g} / \mathrm{kg} \mathrm{MBW} / \mathrm{d})=28.2+0.860$ ADG $(\mathrm{g} / \mathrm{kg}$ $\mathrm{MBW} / \mathrm{d})$

$\left(\mathrm{N}=26 ; \mathrm{P}<0.001 ; \mathrm{R}^{2}=0.829\right)$

Fat-tailed breed: TDNI (g/kg MBW/d)=27.5 +1.22 ADG (g/kg $\mathrm{MBW} / \mathrm{d})$

$\left(\mathrm{N}=9 ; \mathrm{P}=0.019 ; \mathrm{R}^{2}=0.568\right)$

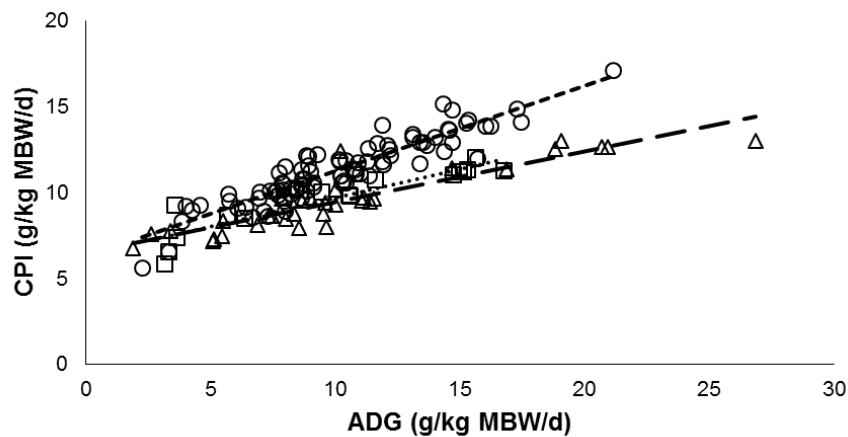

Figure 5. Relationship between crude protein intake (CPI, g/kg $\mathrm{MBW} / \mathrm{d}$ ) and average daily gain (ADG, $\mathrm{g} / \mathrm{kg} \mathrm{MBW/d}$ ) of local (-o-), Priangan (- $\left.\Delta^{-}\right)$and fat-tailed (- -$)$sheep breeds.

Local breed $\quad:$ CPI $(\mathrm{g} / \mathrm{kg} \mathrm{MBW} / \mathrm{d})=6.27+0.497 \mathrm{ADG}(\mathrm{g} / \mathrm{kg}$ $\mathrm{MBW} / \mathrm{d})$ $\left(\mathrm{N}=88 ; \mathrm{P}<0.001 ; \mathrm{R}^{2}=0.844\right)$

Priangan breed : CPI (g/kg MBW/d) $=6.47+0.295$ ADG $(\mathrm{g} / \mathrm{kg}$ $\mathrm{MBW} / \mathrm{d})$

$\left(\mathrm{N}=33 ; \mathrm{P}<0.001 ; \mathrm{R}^{2}=0.823\right)$

Fat-tailed breed : CPI $(\mathrm{g} / \mathrm{kg} \mathrm{MBW} / \mathrm{d})=6.33+0.336 \mathrm{ADG}(\mathrm{g} / \mathrm{kg}$ $\mathrm{MBW} / \mathrm{d})$

$\left(\mathrm{N}=16 ; \mathrm{P}<0.001 ; \mathrm{R}^{2}=0.851\right)$

Table 3. Recommended dry matter, energy (total digestible nutrient, TDN) and crude protein (CP) intake for local, Priangan and fattailed sheep in Indonesia

\begin{tabular}{|c|c|c|c|c|c|c|c|c|c|c|}
\hline \multirow{2}{*}{$\begin{array}{l}\text { BW } \\
(\mathrm{kg})\end{array}$} & \multirow{2}{*}{$\begin{array}{l}\text { ADG } \\
(\mathrm{g} / \mathrm{d})\end{array}$} & \multicolumn{3}{|c|}{ Local (g/d) } & \multicolumn{3}{|c|}{ Priangan $(\mathrm{g} / \mathrm{d})$} & \multicolumn{3}{|c|}{ Fat-tailed $(\mathrm{g} / \mathrm{d})$} \\
\hline & & $\mathrm{DM}$ & TDN & $\mathrm{CP}$ & $\mathrm{DM}$ & TDN & $\mathrm{CP}$ & $\mathrm{DM}$ & TDN & $\mathrm{CP}$ \\
\hline \multirow[t]{4}{*}{10} & 0 & 324 & 152 & 35 & 324 & 159 & 36 & 324 & 155 & 36 \\
\hline & 50 & 434 & 289 & 60 & 434 & 202 & 51 & 434 & 216 & 52 \\
\hline & 100 & 544 & 427 & 85 & 544 & 245 & 66 & 544 & 277 & 69 \\
\hline & 150 & 654 & 564 & 110 & 654 & 288 & 81 & 654 & 338 & 86 \\
\hline \multirow[t]{4}{*}{15} & 0 & 439 & 206 & 48 & 439 & 215 & 49 & 439 & 210 & 48 \\
\hline & 50 & 549 & 343 & 73 & 549 & 258 & 64 & 549 & 271 & 65 \\
\hline & 100 & 659 & 481 & 97 & 659 & 301 & 79 & 659 & 332 & 82 \\
\hline & 150 & 769 & 618 & 122 & 769 & 344 & 94 & 769 & 393 & 99 \\
\hline \multirow[t]{4}{*}{20} & 0 & 545 & 255 & 59 & 545 & 267 & 61 & 545 & 260 & 60 \\
\hline & 50 & 655 & 393 & 84 & 655 & 310 & 76 & 655 & 321 & 77 \\
\hline & 100 & 765 & 530 & 109 & 765 & 353 & 91 & 765 & 382 & 93 \\
\hline & 150 & 875 & 668 & 134 & 875 & 396 & 105 & 875 & 443 & 110 \\
\hline \multirow[t]{4}{*}{25} & 0 & 644 & 302 & 70 & 644 & 315 & 72 & 644 & 307 & 71 \\
\hline & 50 & 754 & 439 & 95 & 754 & 358 & 87 & 754 & 368 & 88 \\
\hline & 100 & 864 & 577 & 120 & 864 & 401 & 102 & 864 & 429 & 104 \\
\hline & 150 & 974 & 714 & 145 & 974 & 444 & 117 & 974 & 490 & 121 \\
\hline \multirow[t]{4}{*}{30} & 0 & 738 & 346 & 80 & 738 & 361 & 83 & 738 & 353 & 81 \\
\hline & 50 & 848 & 484 & 105 & 848 & 404 & 98 & 848 & 414 & 98 \\
\hline & 100 & 958 & 621 & 130 & 958 & 447 & 112 & 958 & 475 & 115 \\
\hline & 150 & 1068 & 759 & 155 & 1068 & 490 & 127 & 1068 & 536 & 132 \\
\hline
\end{tabular}

Note: BW, body weight; ADG, average daily gain.

factors that affect intake are feeding systems and strategies, housing management, ambient temperature and humidity (Nikkhah, 2014). Further, Lewis \& Emmans (2010) observed that feed intake of sheep were affected by body weight, breed, sex and feed composition.
Numerous factors have been attempted to predict dry matter intake of ruminants, and body weight of the animals is considered as one of the most reliable factors for such prediction. Salah et al. (2014), for instance, estimated DMI from BW with a coefficient determination 
of 0.91. The NRC (2007) also used BW in the terms of standard reference weight and relative size to estimate intake of sheep with a number of correction factors such as sheep physiological state and diet quality (legume content and quality of the legume).

\section{Energy Requirement of Sheep}

Expression of energy intake found in feeding experiments using sheep in Indonesia was generally in the form of TDN. This energy system is actually not ideal and therefore, current system has to be moved towards metabolizable energy (ME) or even net energy (NE) system (NRC, 2007; Van Duinkerken et al., 2011; Van Amburgh et al., 2015). Further, TDN data from various diets were obtained by estimations from their chemical composition and seldomly derived experimentally; such predictions may not be accurate since no study so far, to our knowledge, has validated the relationship between estimated TDN and measured TDN in the country. It is apparent that in the future we should update our energy system. Measurement of gross energy (GE) is presently available in many laboratories related to animal nutrition in Indonesia. Derivation of digestible energy (DE) value is relatively simple by combining GE intake and digestibility coefficient of the diet. Determination of ME requires a certain equipment to measure loss of energy as methane. In the case of unavailable or insufficient data of methane emissions across various dietary regimes, a number of equations to estimate methane emissions from sheep are available (Sejian et al., 2011; Vetharaniam et al., 2015) and may be used to derive ME from DE data.

Requirement of TDN obtained in the present study is apparently higher in comparison to the recommendation of NRC (2007). For instance, a growing lamb with $\mathrm{BW}$ of $20 \mathrm{~kg}$ and ADG $100 \mathrm{~g} / \mathrm{d}$ requires $300 \mathrm{~g}$ TDN/d (NRC, 2007). At similar BW and ADG, local sheep, Priangan and fat-tailed breeds require 530, 353 and 382 g TDN/d, respectively. Nevertheless, Kearl (1982) suggested that sheep with such BW and ADG required $470 \mathrm{~g}$ TDN/d which is in accordance with our present result. Salah et al. (2014) reported that, by using a meta-analysis study, $\mathrm{ME}_{\mathrm{m}}$ requirements of tropical and temperate sheep are 423.7 and $361.2 \mathrm{~kJ} / \mathrm{kg} \mathrm{MBW}$, respectively. These value are equal to 28.1 and $23.9 \mathrm{~g}$ TDN/kg $\mathrm{MBW} / \mathrm{d}$, respectively, taking into consideration that 1 $\mathrm{kg}$ TDN= 4.4 Mcal DE and ME= DE $\times 0.82(\mathrm{NRC}, 2007)$. Our TDN ${ }_{\mathrm{m}}$ values ranged from 27.0 to $28.2 \mathrm{~g} / \mathrm{kg} \mathrm{MBW} / \mathrm{d}$ which were quite comparable to the value of $\mathrm{ME}_{\mathrm{m}}$ of tropical sheep (Salah et al., 2014). Further, $\mathrm{ME}_{\mathrm{g}}$ of tropical and temperate sheep are 17.6 and $16.4 \mathrm{~kJ} / \mathrm{g}$ ADG, respectively (Salah et al., 2014), which are equal to 1.166 and $1.086 \mathrm{~g}$ TDN/g ADG. In comparison to such recommendation, our $\mathrm{TDN}_{\mathrm{g}}$ value was lower for Priangan breed but higher for local and fat-tailed breeds.

Our results suggested a higher TDN requirement in comparison to NRC (2007) standard. To make the recommendation, NRC (2007) employed a database from 31 references with 156 observations from 1,875 sheep in which the sheep genotype presented was of temperate origin such as Dorset, Rambouillet, St. Croix, Hampshire, Suffolk and many others. On the contrary, our database was developed by using sheep genotype of tropical origin and thus apparently more appropriate with the recommendation of Kearl (1982). Tropical genotypes generally are not selected for muscle deposition and, hence, tend to be fatter as compared to those of temperate genotypes (Chay-Canul et al., 2011). In consequence, tropical genotypes require more energy for ADG than the temperate genotypes. Further, under high temperature conditions prevailing in the tropics, sheep require more energy to dissipate body heat and therefore increase the energy requirement of the animal (CSIRO, 2007). Another factor that may explain such higher energy requirement of sheep obtained in this study is the diet. Tropical sheep are generally fed with agricultural by-products that rich in fiber contents (Zain, 2009; Ginting et al., 2013; Ndaru et al., 2014). Such fibrous feeds may increase heat production, visceral energy consumption, energy needed for intake and chewing, energy expenditure, and finally total energy requirement of ruminants (Salah et al., 2014).

Comparing among different sheep breeds evaluated in the present meta-analysis study, it was clear that the order of $\mathrm{TDN}_{\mathrm{g}}$ requirement was as follow: Priangan $<$ fat-tailed $<$ local. This indicates that Priangan sheep is more efficient in converting energy intake into body mass as compared to the other two breeds, and local breed is the least efficient. This result is in agreement with Sumantri et al. (2007) who observed that body weight and body size of Priangan (Garut) sheep were higher as compared to other breeds, including local sheep from Jonggol and fat-tailed sheep from various locations (Madura, Donggala, Kisar, Rote, and Sumbawa). It seems that genetic potential of Priangan sheep is better since the breed was a cross between local, Merino and fat-tailed sheep (Inounu, 2011), thus inherited all the excellent characteristics from the three breeds. Aditionally, Priangan sheep have been genetically selected for superior agility and accompanied with good feeding and raising practices particularly in Garut region (Inounu, 2011). On the contrary, local sheep receive much less attention with regard to genetic selection, breeding, feeding and management practices thus contributing to their low production merit. Body compositions of different sheep breeds apparently also influence their $\mathrm{TDN}_{\mathrm{g}}$ requirements. Baihaqi \& Herman (2012) reported that carcass of Priangan breed had more muscle and less fat at mature live weight than that of fat-tailed breed. At a slaughter weight of $32.5 \mathrm{~kg}$, Priangan breed contained $4.85 \mathrm{~kg}$ muscle and $2.28 \mathrm{~kg}$ fat, whereas fat-tailed breed contained $4.49 \mathrm{~kg}$ muscle and $2.73 \mathrm{~kg}$ fat. Similarly, at a slaughter weight of 40 $\mathrm{kg}$, muscle contents in Priangan and fat-tailed breeds were 5.70 and $5.03 \mathrm{~kg}$, respectively, while their fat contents were 2.66 and $3.70 \mathrm{~kg}$, respectively (Baihaqi \& Herman, 2012). Since fat synthesis requires more energy, it is therefore obvious that fat-tailed sheep require more $\mathrm{TDN}_{\mathrm{g}}$ than that of Priangan. 


\section{Protein Requirement of Sheep}

Expression of protein intake found in feeding experiments using sheep in Indonesia was in the form of crude protein $(\mathrm{CP})$. This system is less accurate and current system has to be shifted to metabolizable protein (MP) system or its equivalent (NRC, 2007; Van Duinkerken et al., 2011; Das et al., 2014; Owens et al., 2014; Van Amburgh et al., 2015). The old CP system has a main disadvantage, i.e. it does not differentiate between protein requirement of rumen microbes and protein requirement of the host animal (Das et al., 2014). The MP system, conversely, addresses both the need of $\mathrm{N}$ for rumen microbes and postruminal need of amino acids for maintenance and growth of the host ruminant (Owens et al., 2014). By employing the MP system, basic goals in protein nutrition of ruminants can be achieved, i.e. (1) to meet rumen degradable protein (RDP) requirement of rumen microbes for maximum carbohydrate digestion and microbial protein synthesis, (2) to meet MP requirement of host animal for maintenance, growth, optimum health, and reproduction with minimum intake of rumen undegradable protein (RUP), and (3) to meet $\mathrm{MP}$ and amino acids requirements of the host animal for a desired production level with minimum dietary CP (Das et al., 2014). Even though MP system is preferable as compared to CP system, such application may be difficult due to limited data available like the case in Indonesia. An alternative solution is to predict MP from CP; dietary MP concentration ranges from 64 to $80 \%$ of $\mathrm{CP}$ with diets of 0 to $100 \%$ of RUP, respectively (NRC, 2007). So if the proportion of RUP is known then MP can be estimated. But if RUP is unknown then using CP system is still acceptable (Owens et al., 2014).

As of TDN, CP requirement of Indonesian sheep obtained by using meta-analysis approach is higher than the NRC (2007) recommendation. Local, Priangan and fat-tailed sheep with BW $20 \mathrm{~kg}$ and ADG $100 \mathrm{~g} / \mathrm{d}$ would require 109, 91 and $93 \mathrm{~g} \mathrm{CP/d}$, respectively, whereas NRC (2007) recommends 69-76 g CP/d that depends on RUP proportion in the diet; higher RUP proportion leads to lower CP requirement. Accordingly, Kearl (1982) recommended $72 \mathrm{~g} \mathrm{CP} / \mathrm{d}$ for sheep with similar BW and ADG. Salah et al. (2014) reported that digestible $\mathrm{CP}(\mathrm{DCP})$ requirements of tropical and temperate sheep genotypes were similar; $\mathrm{DCP}$ requirement for maintenance $\left(\mathrm{DCP}_{\mathrm{m}}\right)$ and gain $\left(\mathrm{DCP}_{\mathrm{g}}\right)$ was $2.8 \mathrm{~g} / \mathrm{kg} \mathrm{MBW}$ and $0.2 \mathrm{~g} / \mathrm{g} \mathrm{ADG}$, respectively. Assuming a CP digestibility of $70 \%$ in mixed diets consumed by sheep (Zagorakis et al., 2015; Aemiro et al., 2017), the $\mathrm{CP}_{\mathrm{m}}$ and $\mathrm{CP}_{\mathrm{g}}$ requirements become $4.0 \mathrm{~g} / \mathrm{kg} \mathrm{MBW}$ and $0.286 \mathrm{~g} / \mathrm{g}$ ADG, respectively. Our $\mathrm{CP}_{\mathrm{m}}$ and $\mathrm{CP}_{\mathrm{g}}$ values for all sheep breeds evaluated were higher in comparison to those of Salah et al. (2014). It has to be noted that such CP requirements may have to be adjusted according to variation in dietary CP digestibility; among the factors that influence the digestibility or nitrogen retention are nitrogen intake, faecal nitrogen excretion and urinary nitrogen excretion (Schuba et al., 2017). Further, presence of dietary factors that influence the proportion between RDP to RUP may also change $\mathrm{CP}_{\text {r }}$ requirement. Among them are polyphenols or tannins that shift towards more
RUP proportion since the compounds are able to form complexes with dietary protein and protect the nutrient from microbial degradation in the rumen (Jayanegara et al., 2013; 2015).

Higher $\mathrm{CP}$ requirement obtained in this study probably is a reflection of the difference between tropical and temperate sheep breeds in which the tropical breed has generally lower growth potential (Chay-Canul et al., 2011) as previously described. High environmental temperature in the tropics may also explain such high $\mathrm{CP}_{\mathrm{m}}$ and $\mathrm{CP}_{\mathrm{g}}$ requirements obtained in the current study. It has been described that high temperature is associated with an increase of absorbed amino acid requirement for growth in ruminants (Salah et al., 2014). Lower $\mathrm{CP}_{\mathrm{g}}$ requirement of Priangan breed confirms superiority of the breed as compared to fat-tailed and local breeds (Sumantri et al., 2007; Inounu, 2011).

\section{CONCLUSION}

Each sheep breed in Indonesia has specific TDN and $\mathrm{CP}$ requirements. Although energy and protein requirements for maintenance $\left(\mathrm{TDN}_{\mathrm{m}}\right.$ and $\mathrm{CP}_{\mathrm{m}}$ ) are similar across sheep breeds, different sheep breeds have significantly different energy and protein requirements for gain $\left(\mathrm{TDN}_{\mathrm{g}}\right.$ and $\left.\mathrm{CP}_{\mathrm{g}}\right)$. Priangan sheep requires less $\mathrm{TDN}_{\mathrm{g}}$ and $\mathrm{CP}_{\mathrm{g}}$ in comparison to fat-tailed and local breeds, and local breed possesses higher $\mathrm{TDN}_{\mathrm{g}}$ and $\mathrm{CP}_{\mathrm{g}}$ requirements than those of the fat-tailed. Further studies are required to validate the current results of energy and protein requirements for Indonesian sheep.

\section{ACKNOWLEDGMENT}

This research was funded by Indonesian Ministry of Research, Technology and Higher Education through "Penelitian Unggulan Perguruan Tinggi - Penelitian Unggulan Divisi" research grant.

\section{REFERENCES}

Adawiah, T. Sutardi, T. Toharmat, W. Manalu, Nahrowi, \& U. H. Tanuwiria. 2006. Supplementation of mineral soap and organic mineral and roasted soybean to sheep. Med. Pet. 29:27-34.

Aemiro, A., P. Kiiru, S. Watanabe, K. Suzuki, M. Hanada, K. Umetsu, \& T. Nishida. 2017. The effect of euglena (Euglena gracilis) supplementation on nutrient intake, digestibility, nitrogen balance and rumen fermentation in sheep. Anim. Feed Sci. Technol. 225:123-133. https://doi.org/10.1016/j. anifeedsci.2017.01.017

Aqbari, D., A. H. Daulay, \& I. Sembiring. 2015. Utilization of oil palm frond fermented by level Biomol+ for male sheep fattening. J. Pet. Integ. 3:259-267.

Baihaqi, M., \& R. Herman. 2012. Carcass and non-carcass components of Priangan and Javanese fat-tailed rams slaughtered at mature live weight. Med. Pet. 35:196-200. https:// doi.org/10.5398/medpet.2012.35.3.196

Braymana, B. S., I. Sembiring, \& U. Budi. 2014. Utilization of pelleting banana crop residue to substitute grass on performances of weaning male local sheep. J. Pet. Integ. 2:102-111.

Chay-Canul, A. J., A. J. Ayala-Burgos, J. C. Ku-Vera, J. G. Magana-Monforte, \& C. L. Ferrell. 2011. Metabolizable 
energy intake and changes in body weight and body condition of Pelibuey ewes fed three levels of roughage diets under tropical conditions. Trop. Subtrop. Agroecosyst. 14:777-786.

Chizzotti, M. L., S. C. V. Filho, L. O. Tedeschi, F. H. M. Chizzotti, \& G. E. Carstens. 2007. Energy and protein requirements for growth and maintenance of $F_{1}$ Nellore $x$ Red Angus bulls, steers, and heifers. J. Anim. Sci. 85:19711981. https://doi.org/10.2527/jas.2006-632

Chizzotti, M. L., L. O. Tedeschi, \& S. C. V. Filho. 2008. A metaanalysis of energy and protein requirements for maintenance and growth of Nellore cattle. J. Anim. Sci. 86:15881597. https://doi.org/10.2527/jas.2007-0309

CSIRO (Commonwealth Scientific and Industrial Research Organization). 2007. Nutrient Requirements of Domesticated Ruminants. CSIRO Publishing, Collingwood, Australia.

Das, L. K., S. S. Kundu, D. Kumar, \& C. Datt. 2014. Metabolizable protein systems in ruminant nutrition: A review. Vet. World 7:622-629. https://doi.org/10.14202/ vetworld.2014.622-629

Dong, L. F., T. Yan, C. P. Ferris, \& D. A. McDowell. 2015. Comparison of maintenance energy requirement and energetic efficiency between lactating Holstein-Friesian and other groups of dairy cows. J. Dairy Sci. 98:1136-1144. https://doi.org/10.3168/jds.2014-8629

Duldjaman, M. 2004. Utilization of tofu by-product to improve nutritional status of local sheep. Med. Pet. 27:107-110.

Ekawati, E., A. Muktiani, \& Sunarso. 2014. Efficiency and digestibility feed of sheep given silage complete feed water hyacinth added starter Lactobacillus plantarum. Agripet 14:107-114. https://doi.org/10.17969/agripet.v14i2.1885

Ginting, H. S., Z. Siregar, \& E. Mirwandhono. 2013. Effect of rice straw with different treatment (physical, chemical, biological and combination) on performance of local rams. J. Pet. Integ. 1:155-164.

Hartutik, Soebarinoto, \& R. Y. Matrif. 2010. Concentrates substitution with cassava leaf (Manihot esculenta Crantz) and gliricidia (Gliricidia sepium Jacq) mixtures silage on fat tailed sheep performance. J. Ilmu Pet. 20:22-30.

Hernaman, I., T. Toharmat, W. Manalu, \& P. I. Pudjiono. 2011. Performance of sheep fed diet containing Zn-phytate and $\mathrm{Pb}$-acetate. J. Ilmu Ternak 10:57-60.

Indarsih, B. 2009. Response of two different strains of commercial broilers to different dietary amino acid allowance. Med. Pet. 32:104-111.

Inounu, I. 2011. The establishment of composite sheep through cross-breeding technology in efforts to improve genetic quality of local sheep. Pengembangan Inovasi Pertanian 4:218-230.

Jayanegara, A., S. Marquardt, E. Wina, M. Kreuzer, \& F. Leiber. 2013. In vitro indications for favourable non-additive effects on ruminal methane mitigation between highphenolic and high-quality forages. Br. J. Nutr. 109:615-622. https://doi.org/10.1017/S0007114512001742

Jayanegara, A., E. Wina, \& J. Takahashi. 2014. Meta-analysis on methane mitigating properties of saponin-rich sources in the rumen: influence of addition levels and plant sources. Asian Australas. J. Anim. Sci. 27:1426-1435. https://doi. org/10.5713/ajas.2014.14086

Jayanegara, A., G. Goel, H. P. S. Makkar, \& K. Becker. 2015. Divergence between purified hydrolysable and condensed tannin effects on methane emission, rumen fermentation and microbial population in vitro. Anim. Feed Sci. Technol. 209:60-68. https://doi.org/10.1016/j.anifeedsci.2015.08.002

Kearl, L. C. 1982. Nutrient Requirements of Ruminants in Developing Countries. Utah State University, Logan, USA.

Ketaren, M. F., T. H. Wahyuni, \& Z. Siregar. 2013. Utilization of fermented rice straw by MOD-71 on performances of Sei
Putih lamb. J. Pet. Integ. 1:266-275.

Khotijah, L., R. Zulihar, M. A. Setiadi, K. G. Wiryawan, \& D. A. Astuti. 2014. Effect of sun flower oil addition (Helianthus annuus) in diet on nutrient intake, growth performance and characteristics of estrous pre-mating Garut sheep. JITV 19:9-16.

Lestari, D. A., L. Abdullah, \& Despal. 2015. Comparative study of milk production and feed efficiency based on farmers best practices and National Research Council. Med. Pet. 38:110-117. https://doi.org/10.5398/medpet.2015.38.2.110

Lewis, R. M., \& G. C. Emmans. 2010. Feed intake of sheep as affected by body weight, breed, sex, and feed composition. J. Anim. Sci. 88:467-480. https://doi.org/10.2527/jas.2008-1735

Lubis, D., E. Wina, \& B. E. Rubiono. 1998. Growth rate of sheep fed high fat ration. JITV 3:143-148.

Lubis, D., B. Haryanto, E. Wina, \& T. Suhargiyantatmo. 2002. Feeding of Aspergillus oryzae fermentation culture (AOFC) to growing sheep: 2 . Growth rate and feed efficiency. JITV 7:214-219.

Mahyuddin. 2001. Effect of feeding substitution of feather meal and rice bran on body weight, feed consumption and feed efficiency of the local lambs. Agripet 2:1-6.

Mathius, I. W., M. Martawidjaja, A. Wilson, \& T. Manurung. 1996. Strategic study on energy-protein requirements for local sheep: 1. Growing phase. JITV 2:84-91.

Mathius, I. W., D. Lubis, E. Wina, D. P. Nurhayati, \& I. G. M. Budiarsana. 1997. Additional calcium carbonate into concentrate diet for sheep fed ensiled king grass as a baseddiet. JITV 2:164-169.

Mathius, I. W., B. Haryanto, \& I. W. R. Susana. 1998. Influence of feeding protected protein and energy on intake and digestion by lambs. JITV 3:94-100.

Nababan, N. N., T. H. Wahyuni, \& N. D. Hanafi. 2014 Utilization of fermented water hyacinth as a feed on weaning local male sheep. J. Pet. Integ. 2:173-182.

Ndaru, P. H., Kusmartono, \& S. Chuzaemi. 2014. Effect of cassava leaves (Manihot utilissima Pohl) supplementation at various levels on productivity of fat-tailed sheep fed maize stover (Zea mays) as basal feed. J. Ilmu Pet. 24:9-25.

NRC (National Research Council). 2000. Nutrient Requirements of Beef Cattle. $7^{\text {th }}$ Ed. National Academy Press, Washington DC, USA.

NRC (National Research Council). 2007. Nutrient Requirements of Small Ruminants: Sheep, Goats, Cervids, and New World Camelids. National Academy Press, Washington DC, USA.

Oliveira, A. S. 2015. Meta-analysis of feeding trials to estimate energy requirements of dairy cows under tropical condition. Anim. Feed Sci. Technol. 210:94-103. https://doi. org/10.1016/j.anifeedsci.2015.10.006

Owens, F. N., S. Qi, \& D. A. Sapienza. 2014. Applied protein nutrition of ruminants: Current status and future directions. Prof. Anim. Sci. 30:150-179. https://doi.org/10.15232/ S1080-7446(15)30102-9

Palupi, E., A. Jayanegara, A. Ploeger, \& J. Kahl. 2012. Comparison of nutritional quality between conventional and organic dairy products: a meta-analysis. J. Sci. Food Agric. 92:2774-2781. https://doi.org/10.1002/jsfa.5639

Puastuti, W., I. W. Mathius, \& D. Yulistiani. 2006. Banana stem juice protected soybean meal as feed supplement to sheep: In sacco and in vivo. JITV 11:106-115.

Puastuti, W., D. Yulistiani, I. W. Mathius, F. Giyai, \& E. Dihansih. 2010. Cacao pod based ration supplemented with organic Zn: Growth response of sheep. JITV 15:269-277.

Riaz, M. Q., K. H. Sudekum, M. Clauss, \& A. Jayanegara. 2014. Voluntary feed intake and digestibility of four domestic ruminant species as influenced by dietary constituents: a meta-analysis. Livest. Sci. 162:76-85. https://doi. 
org/10.1016/j.livsci.2014.01.009

Rimbawanto, E. A., Suwandyastuti, \& S. Rahayu. 2012. Biotransformation of fish waste as feed matter for ruminant. Agripet 12:41-46. https:/doi.org/10.17969/agripet. v12i1.287

Salah, N., D. Sauvant, \& H. Archimede. 2014. Nutritional requirements of sheep, goats and cattle in warm climates: a meta-analysis. Animal 8:1439-1447. https://doi.org/10.1017/ S1751731114001153

Schuba, J., K. H. Sudekum, E. Pfeffer, \& A. Jayanegara. 2017. Excretion of faecal, urinary urea and urinary non-urea nitrogen by four ruminant species as influenced by dietary nitrogen intake: A meta-analysis. Livest. Sci. 198:82-88. https://doi.org/10.1016/j.livsci.2017.01.017

Sejian, V., R. Lal, J. Lakritz, \& T. Ezeji. 2011. Measurement and prediction of enteric methane emission. Int. J. Biometeorol. 55:1-16. https://doi.org/10.1007/s00484-010-0356-7

Simanjuntak, S., Yunilas, \& M. Tafsin. 2015. Fermented oil palm industry and plantation by product by local probiotics on performances of sheep. J. Pet. Integ. 4:83-95.

Sitanggang, C. E., Z. Siregar, \& N. Ginting. 2013. Utilization of rice straw fermented by probiotics Starbio on the growth of local rams. J. Pet. Integ. 1:215-223.

St-Pierre, N. R. 2001. Integrating quantitative findings from multiple studies using mixed model methodology. J. Dairy Sci. 84: 741-755.

Sudarman, A., K. G. Wiryawan, \& H. Markhamah. 2008. Addition of Sardinella longiceps oil in the form of Ca-soap into the ration: 1 . Its effects on sheep performance. Med. Pet. 31:166-171.

Sumantri, C., A. Einstiana, J. F. Salamena, \& I. Inounu. 2007. Performances and phylogenic relationships among local sheep in Indonesia by morphological analysis. JITV 12:42-54.

Supriyati \& B. Haryanto. 2007. The effect of supplementation of $\mathrm{Zn}$-biocomplex in ration on the growth of young sheep. JITV 12:268-273.

Supriyati. 2008. The effect of Zink-biocomplex and Zinkmethionate supplementation on the ration for lambs. JITV 13:89-94.

Tanuwiria, U. H., \& B. Ayuningsih. 2008. The effects of Znproteinate, Cu-proteinate and Ca-fish oil complex in canetop ammoniated based ration on Priangan $\times$ Barbados cross male sheep performance. J. Ilmu Ternak 8:7-12.

Tarmidi, A. R. 2004. The effect of sugar cane waste product fermented by Pleurotus ostreatus on the ration to Priangan sheep performance. JITV 9:157-163.

Thalib, A., Y. Widiawati, H. Hamid, D. Suherman, \& M. Sabrani. 1996. The effects of saponin from Sapindus rarak fruit on rumen microbes and performance of sheep. JITV 2:17-21.

Thalib, A., \& Y. Widiawati. 2008. Effect of Acetoanaerobium noterae bacteria addition in the diet on methane production and performance of sheep. JITV 13:273-278.

Thalib, A., Y. Widiawati, \& B. Haryanto. 2010. Utilization of complete rumen modifier on sheep fed high fibrous forages. JITV 15:97-104.

Tiven, N. C., L. M. Yusiati, Rusman, \& U. Santoso. 2015. The effect of CPO protected with formaldehyde on digestibility and performance of thin tail sheep. Bul. Pet. 39:78-83.
Uhi, H. T. 2006. Comparative of catalytic supplement and soybean meal on performance of sheep. J. Ilmu Ternak 6:1-6.

Van Amburgh, M. E., E. A. Collao-Saenz, R. J. Higgs, D. A. Ross, E. B. Rectenwald, E. Raffrenato, L. E. Chase, T. R. Overton, J. K. Mills, \& A. Foskolos. 2015. The Cornell Net Carbohydrate and Protein System: Updates to the model and evaluation of version 6.5. J. Dairy Sci. 98:6361-6380. https://doi.org/10.3168/jds.2015-9378

Van Duinkerken, G., M. C. Blok, A. Bannink, J. W. Cone, J. Dijkstra, A. M. Van Vuuren, \& S. Tamminga. 2011. Update of the Dutch protein evaluation system for ruminants: The DVE/OEB 2010 system. J. Agric. Sci. 149:351367. https://doi.org/10.1017/S0021859610000912

Vetharaniam, I., R. E. Vibart, M. D. Hanigan, P. H. Janssen, M. H. Tavendale, \& D. Pacheco. 2015. A modified version of the Molly rumen model to quantify methane emissions from sheep. J. Anim. Sci. 93:3551-3563. https://doi. org/10.2527/jas.2015-9037

Wati, N. E., L. K. Nuswantara, F. Wahyono, E. Pangestu, \& J. Achmadi. 2015. The effects of synchronization of carbohydrate and protein supply in sugarcane bagasse based ration on body composition of sheep. J. Indonesian Trop. Anim. Agric. 40:222-228. https://doi.org/10.14710/ jitaa.40.4.222-228

Widiyanto, Surahmanto, Mulyono, \& E. Kusumanti. 2011. Pelleted field grass to increase the Java thin tail sheep productivity. J. Indonesian Trop. Anim. Agric. 36:273-280. https://doi.org/10.14710/jitaa.36.4.273-280

Widiyanto, M. Soejono, H. Hartadi, Z. Bachrudin, \& Surahmanto. 2012. Inclusion of kapok seed oil in the diet for growing of thin-tailed sheep to reduce cholesterol and to improve omega-six fatty acid contents of lamb. J. Indonesian Trop. Anim. Agric. 37:202-212. https://doi. org/10.14710/jitaa.37.3.202-212

Wiryawan, K. G., A. Parakkasi, R. Priyanto, \& I. P. Nanda. 2007. The use of formaldehyde protected palm kernel meal and its effects on animal performance, nitrogen utilization and unsaturated fatty acid composition in Priangan sheep. JITV 12:249-254.

Wulandari, S., A. Agus, M. Soejono, M. N. Cahyanto, \& R. Utomo. 2014. Performance of sheep fed cocoa pod based fermented complete feed and its in vivo nutrient digestion. Bul. Pet. 38:42-50.

Yulistiani, D., I. W. Mathius, \& W. Puastuti. 2011. Substitution of commercial concentrate with soybean meal protected by tannin from banana stem juice for lambs. JITV 16:33-40.

Yulistiani, D., W. Puastuti, \& I. W. Mathius. 2013. Response of sheep on concentrate containing feather meal and supplemented with mineral chromium. JITV 18:9-16.

Zagorakis, K., D. Liamadis, Ch. Milis, V. Dotas, \& D. Dotas. 2015. Nutrient digestibility and in situ degradability of alternatives to soybean meal protein sources for sheep. Small Rum. Res. 124:38-44. https://doi.org/10.1016/j. smallrumres.2015.01.002

Zain, M. 2009. Substitution of native grass with ammoniated cocoa pod in sheep diet. Med. Pet. 32:47-52.

Zhao, J., X. Ma, Y. Jin, R. Su, W. Liu, Y. Ren, C. Zhang, \& J. Zhang. 2016. Energy requirements for the maintenance and growth of Dorper-Jinzhong crossbred ram lambs. Ital. J. Anim. Sci. 15:94-102. https://doi.org/10.1080/182805 1X.2016.1147336 